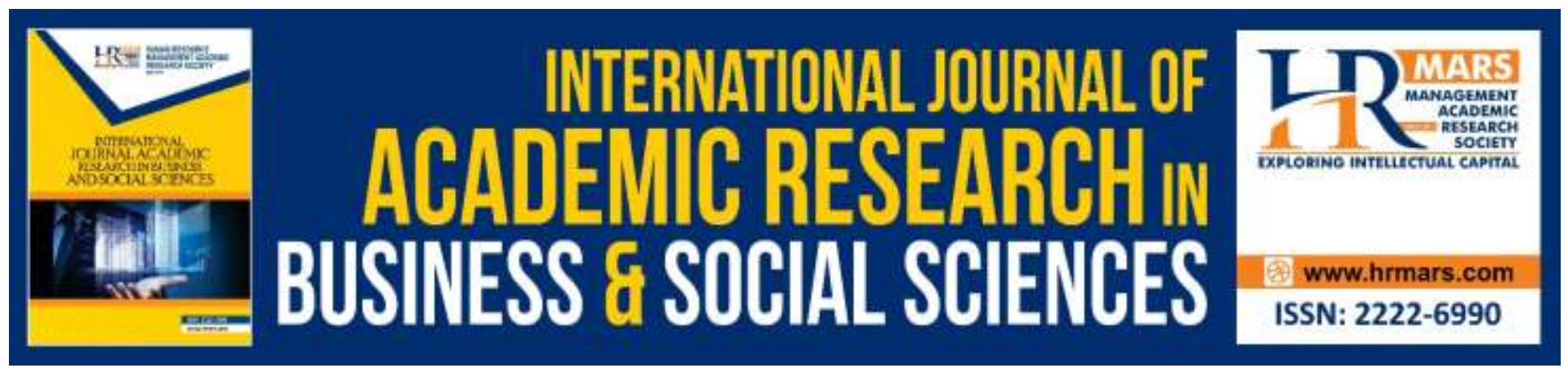

\title{
Is Switching Intention an Alarming Issue for General Insurance Providers? Malaysia's Perspectives
}

Ahmad Fadhly Arham, Nor Sabrena Norizan, Noraznira Abdul Razak, Nurazree Mahmud, Muhamad Nazirul Mohd Hisham, Abdul Rasyid Mohamad Nawi

To Link this Article: http://dx.doi.org/10.6007/IJARBSS/v10-i3/7045 DOI:10.6007/IJARBSS/v10-i3/7045

Received: 02 February 2020, Revised: 22 February 2020, Accepted: 12 March 2020

Published Online: 29 March 2020

In-Text Citation: (Arham et al., 2020)

To Cite this Article: Arham, A. F., Norizan, N. S., Razak, N. A., Mahmud, N., Hisham, M. N. M., \& Nawi, A. R. M. (2020). Is Switching Intention an Alarming Issue for General Insurance Providers? Malaysia's Perspectives. International Journal of Academic Research in Business and Social Sciences, 10(3), 264-271.

Copyright: (C) 2020 The Author(s)

Published by Human Resource Management Academic Research Society (www.hrmars.com)

This article is published under the Creative Commons Attribution (CC BY 4.0) license. Anyone may reproduce, distribute, translate and create derivative works of this article (for both commercial and non-commercial purposes), subject to full attribution to the original publication and authors. The full terms of this license may be seen

at: http://creativecommons.org/licences/by/4.0/legalcode

Vol. 10, No. 3, 2020, Pg. 264 - 271

http://hrmars.com/index.php/pages/detail/IJARBSS

JOURNAL HOMEPAGE

Full Terms \& Conditions of access and use can be found at http://hrmars.com/index.php/pages/detail/publication-ethics 


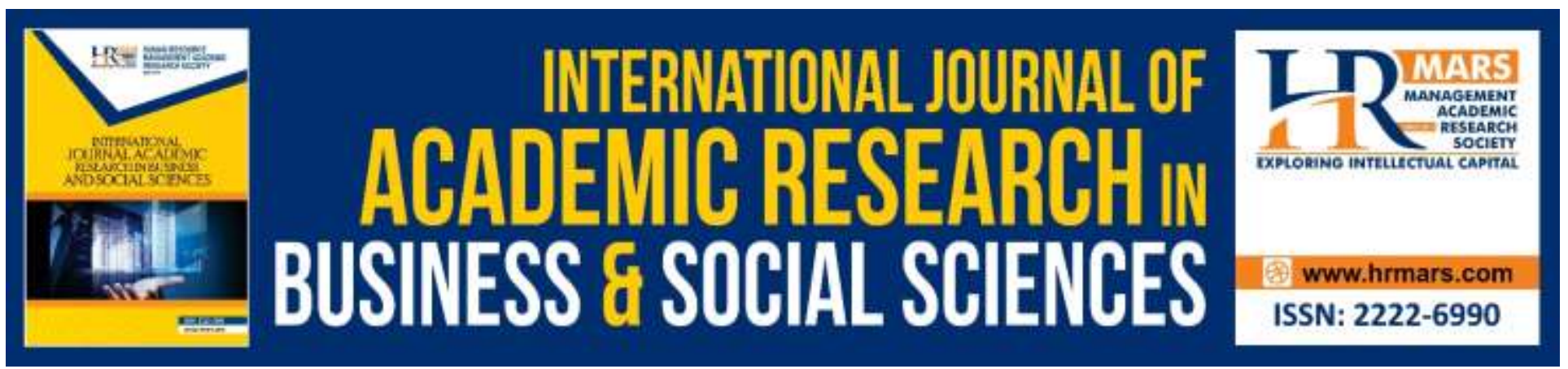

\title{
Is Switching Intention an Alarming Issue for General Insurance Providers? Malaysia's Perspectives
}

\author{
Ahmad Fadhly Arham¹, Nor Sabrena Norizan², Noraznira Abdul \\ Razak $^{3}$, Nurazree Mahmud ${ }^{4}$, Muhamad Nazirul Mohd Hisham ${ }^{5}$, \\ Abdul Rasyid Mohamad Nawi ${ }^{6}$ \\ 1,2,3,4 Faculty of Business Management, Universiti Teknologi MARA, Melaka, ${ }^{5}$ Takaful Ikhlas \\ General Insurance, ${ }^{6}$ Tune Insurance
}

\begin{abstract}
To switch or not to switch? This is the key question that the general insurance policyholders would ask at the end of the term of their insurance contract. The decision to switch or to renew is based on many factors. As such, in this study, service quality, price and trust/loyalty were tested against switching intention. To find answers to this question, a quantitative data collection from 100 general policyholders were obtained and analyzed. The findings indicated that, service quality and price have significant positive relationship towards switching intention. But amongst the three independent variables, only service quality has a significant unique contribution towards switching intention. The implication for the insurance provider included to maintain, sustain and continually enhance the services that they provide to policyholder because dissatisfaction with the services provided might result in the loss of customer which in turn reduce its profitability.

Keywords: Switching Intention, Service Quality, Price, Trust/Loyalty, General Insurance Policy, Malaysia

\section{Introduction}

One of the industries that has not been affected significantly as a result of economic volatility is insurance industry. There has been a steady growth in the industry as the number of policyholders increase dramatically due to increase awareness about the benefits and importance of owning or possessing an insurance policy.
\end{abstract}

Even though this industry is experiencing a steady growth, insurance companies are still facing some operational issues. For example, for life insurance companies, they are experiencing an increase in claim settlement, inability of policyholders to maintain its cover and lapse payment. For general insurance providers, given that the coverage is only for a short-term period (usually within 12 months), one of the major issues that they are dealing with is consumer switch. For example is automobile insurance, in which the policyholders tend to switch insurance providers by at the end of the contract term. Due to experiencing switching among motor insurance policyholders, insurance 
INTERNATIONAL JOURNAL OF ACADEMIC RESEARCH IN BUSINESS AND SOCIAL SCIENCES Vol. 10, No. 3, March, 2020, E-ISSN: 2222-6990 C 2020 HRMARS

companies are implementing and investing various measures to retain the existing ones and to attract new policyholders (Perera \& Gamage, 2019).

Moris (2014) argued that switching intention issue in general insurance is currently alarming in insurance industry. He stated that 1,400,000 general insurance policies are likely to be switched in the next 12 months. Because it only provides a one-year coverage, this short-term coverage has become one of the reasons that contribute to the intention of policyholder to switch their insurance provider. This is the issue being raised in the literature that needs further investigation within the Malaysian context. This study is important especially for many general insurance providers operating in Malaysia. Because switching means loss of customer. Loss of customers means loss of profits to operators.

Even though, statistics have showed that the percentage of policyholder who switched their insurance provider is still relatively low (Figure 1), it still contributes to the loss of income and profit to the insurance provider. In order to maintain a good financial position, minimizing the number of policyholders that changes their insurer is one of the important tasks. To minimize the percentage of switching among general policyholders, it is important to understand the reasons or factors that made them stay and continue to renew their insurance with existing insurance provider. This is the central issue of this study. By investigating the factors that contribute to the switching intention will allow the insurance company to develop strategies that can encourage renewal and thus this will sustain or improve their financial position.

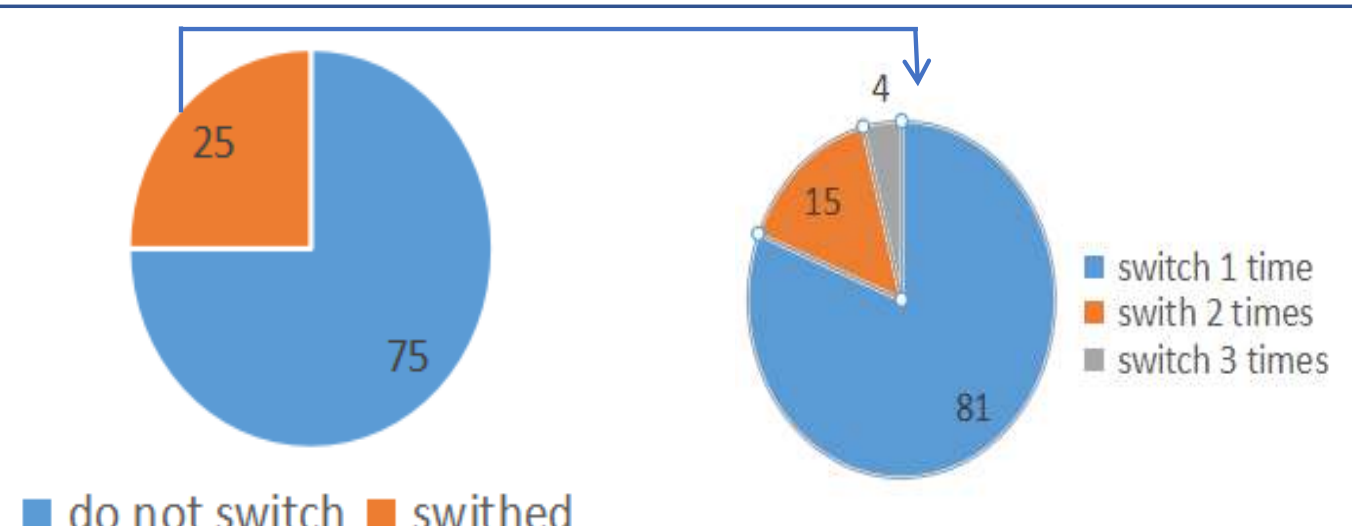

Figure 1: Autopolicy switching behaviour (past 3 years) (nielsen, 2014)

Anton et al. (2007) investigated evidences to the question of why the consumers keep switching or intend to switch. Among the factors in their study were service quality provided by the firms, perceived commitment and price which sometimes can be unfair to the consumers. Furthermore, they also suggested that future study on the intention to switch among policyholders should also include consumer satisfaction and trust/loyalty in pursuance of a better reliability of data collected. Thus, this study will include service quality, price and trust/loyalty as the independent variables and switching intention treated as the dependent variable (Anton et al. 2007).

To the best knowledge of the researchers, there are efforts through research being done on this issue (Anton et al., 2007; Morris, 2014 \& Saeed et al., 2011), but none of them was ever conducted in 
INTERNATIONAL JOURNAL OF ACADEMIC RESEARCH IN BUSINESS AND SOCIAL SCIENCES Vol. 10, No. 3, March, 2020, E-ISSN: 2222-6990 @ 2020 HRMARS

Malaysia. Thus, this study is the initial effort to investigate whether switching intention is a serious matter that needs attention by insurance providers in Malaysia. Thus, the outcome of this study would highlight the reasons behind loss of policyholders to another provider. For the insurance company, outcomes like this will make them aware on factors that will influence policyholders to switch and they can strategize and act even before the policyholders think of switching.

The question is; to switch or not to switch? This is the key question that the policyholder would ask at the end of the term of an insurance contract; general insurance policy in particular. The decision to switch or to renew is based on many factors. Thus, the obejctives of this research are:

1) To examine the level of switching intention in the general insurance market.

2) To identify the relationships between service quality, price and trust/loyalty towards switching intention.

3) To identify factors that contribute significantly towards switching intention?

\section{Switching Intention}

Sambandam and Lord (1995) defined service switching as a person's desire to replace/change his/her current service provider with another competitor. Ajzen (1991) explain that intention to switc refers to a person's intention to migrate (or not migrate) to an improved product version. Meanwhile, (Harrison et al. 2012) stated, switching could occur due to problems with the product, dissatisfaction with the product or alternative firms' enticing the consumer away.

According to Fogli (2006), service quality is a global judgement or attitude relating to a particular service; the customer's overall impression of the relative inferiority or superiority of the organization and its services. Meanwhile Narayanda (1998) finds that a higher expectation of relationship continuity of a consumer possesses a positive attitude toward the service provider as compared to consumer with lower expectation of relationship continuity. He also added, the positive attitudes can be highly beneficial to the organization (Narayanda, 1998).

Another research on service quality was conducted by Srivasta (2014). He found that there is a very strong and positive relationship between customer loyalty and service quality. Furthermore, he argued that customers experiencing cumulatively satisfying experiences are likely to develop positive attitudes towards and a preference for, the service provider.

Zeithaml (1988) stated in his study, from the consumer's perspective, price is what is given up or sacrificed to obtain a product or service. Clemes et al. (2007) highlighted that unfavorable price perceptions can cause customers to switch banks. Based on Asuncion et al. (2004), loyalty has been defined as repeat purchasing frequency or relative volume of same brand purchasing. Furthermore, Mayer et al. (1995) defined trust as "the willingness of the party to be vulnerable to the actions of another party based on the expectation that the other will perform a particular action important to the trust or, irrespective of the ability to monitor or control that other party". Loyalty / trust can be closely related to each other as a trustworthy customer also means a loyal customer toward its service provider and vice versa. 
INTERNATIONAL JOURNAL OF ACADEMIC RESEARCH IN BUSINESS AND SOCIAL SCIENCES

Vol. 10, No. 3, March, 2020, E-ISSN: 2222-6990 @ 2020 HRMARS

\section{Theoretical Framework}

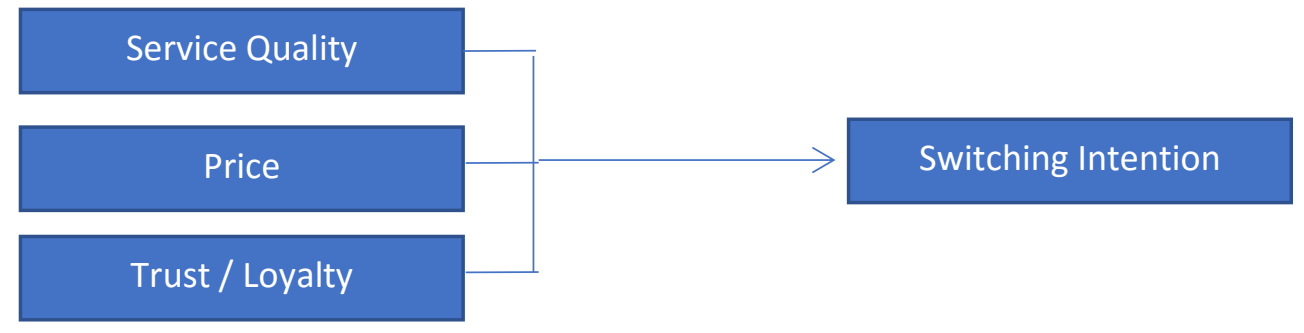

Adapted from: Anto'n et al. (2007)

\section{Research Methodology}

The purpose of this paper is to provide insights into service quality, perceived commitment, price and trust/loyalty which might have contribute to intention to switch insurance company among policyholders. In order to do this, a quantitative data collection and analysis was conducted. Data were collected from general policyholders in the Klang Valley area. Out of 375 questionnaires distributed, only 100 questionnaires were usable in the final data analysis. The convenience sampling approach may limit the generalizability of the findings to the whole population. But, previous research on similar topic, also used the same sampling technique Srivasta (2014).

In order to collect data for this study, the questionnaires were personally distributed and administered by the research assistants. There are five (5) sections in the questionnaire. Section A contains questions on demographic profile, Section B on switching intention, Section C on service quality, Section D on trust/loyalty and Section E on price.

\section{Results and Discussion}

The Cronbach Alphas for all variables were above 0.9, except for switching intention that has an acceptable value of 0.613 . Overall, all measures deemed to demonstrate a good level of internal consistency,

The descriptive analysis of the respondents provided that there were $57.0 \%$ male respondents while $43.0 \%$ of respondents were female. Majority of respondents were Malays with $84.0 \%$ followed by Indian's respondents (8.0\%), Chinese $(7.0 \%)$ and other races represented the remaining $1 \%$ of the sample population. $55 \%$ of the respondents are still single and the remaining were married. With regards to age, $56 \%$ of respondents were between the age of $21-30$ years. $30 \%$ were aged between 31 and 40. Majority of the respondents only made between RM2,001 to RM3,000 per month represented by $37.0 \%, 29 \%$ respondents made between RM3,001 to RM4,000 whereas $19 \%$ has a current income between the range of RM1,001 to RM2,000 per month. Only $5 \%$ of the respondents have a monthly income of more than RM4000 per month. Finally, $61 \%$ of respondents own a degree qualification, $23 \%$ own a diploma.

The mean analysis of independent variable reported that the level of switching intention among general policyholders was moderate $(M=3.187 ; S D=0.914)$. It indicates that switching or intent to switch is not an alarming issue in Malaysia as contemplated by Moris (2014) globally. 
INTERNATIONAL JOURNAL OF ACADEMIC RESEARCH IN BUSINESS AND SOCIAL SCIENCES Vol. 10, No. 3, March, 2020, E-ISSN: 2222-6990 @ 2020 HRMARS

Correlationally, all independent variables have positive relationships towards switching intention. However, only service quality $(r=0.272, p<0.05)$ and price $(r=0.202, p<0.05)$ had significant positive relationships towards switching intention. Policyholders tend to perceive that these are the factors that may influence them to switch. The non-significant relationship between trust/loyalty and switching intention is perhaps due to the perception that the coverage offered between one insurer to another insurer is almost identical to each other. Perhaps, as long as there is no claim being made, many of the policyholders intend to simply renew their policy. If they still intent to switch, other contextual factors may influence their decisions such as relatives or peer pressures who happened to be representative of a different general insurance company or influence by promotional activities conducted by competitors. One of the signals that the general policy insurers need to pick up is that, they must be very concerned when handling claims because it is part of the service quality provided to policyholders. Second, due to the short-term contract, the policyholders have the right to choose which insurance provider could offer them the best rate, assuming same coverage is provided.

The result from analysis of ANOVA reported that the model of this study is significant $(F=3.209$, $p=0.026)$. The results from multiple regression indicated that, the only factor that has significant unique contribution towards switching intention is service quality $(\beta=0.384, p=0.026)$. The other factors, trust trust/loyalty $(\beta=-0.249, p=0.182)$ and price $(\beta=0.108, p=0.548)$ did not have a unique significant contribution towards switching intention.

These outcomes indicate that, in order to minimize switching intention, general insurance companies need to focus on delivering quality of services to policyholders. If they can assure and willing to provide the best services as compared to competitors, the policyholders did not have any valid or eventual reason to switch. Handling claim has always been the most common reason for switching. Besides claim handling process as mentioned to be one of the critical elements of service quality, insurance providers are also encouraged to put in extra efforts by notifying policyholders in advance of the renewal date, notifying consumers about new packages and benefits for renewal and many others.

\section{Limitations and Future Research}

This study is not without limitations. First, the data provided only a snapshot of the study area. Perhaps, a longitudinal data may enhance the quality of findings. Perhaps, future study should include those policyholders who have had the experience of switching in order to get better results. Second, dual language of survey questionnaire should be provided. Looking into the demographic data, majority of respondents were Malays. Thus, if the questionnaire is also available in Bahasa Melayu, this may help some of the respondents to fully understand the requirement of the questions and thus different outcomes may prevail. Finally, for future research, other contextual factor should be considered and included to further understand why customers intent to switch. First, future research should include agents as another independent variable. Agents play a major role in persuading, influencing and encouraging policyholders to buy the policy in the first place. The appearance, politeness, ability to speak with conviction, good rapport and product knowledge are among the possible factors that can cause the policyholders to stay and renew. Employee with good interpersonal skills might affect the company's revenue and also effective in retaining and attracting future consumers to use their services. Other factor could be relative or peer pressures. Some of the policyholders switch because they just want to fulfill the demand from their relatives or friends. Third, 
INTERNATIONAL JOURNAL OF ACADEMIC RESEARCH IN BUSINESS AND SOCIAL SCIENCES

Vol. 10, No. 3, March, 2020, E-ISSN: 2222-6990 @ 2020 HRMARS

the researchers would like to suggest economic as one of the possible factors. When the economic condition is unstable or the country is experiencing inflation, the customer may put the price and the coverage being offered as highly important. Thus, the inclusion of these recommendations may enhance the quality of the findings with regards the intention to switch.

\section{Conclusion}

To conclude, this finding has identified that switching is not a major issue in Malaysia. Thus, insurance providers in Malaysia do not have to worry much about whether their policyholders are planning to switch as it is not an alarming matter as what being claimed by Moris (2014). Practically, based on the findings, insurance companies must strategize on how to maintain and sustain in providing high quality of services. In-line with the finding of this study, Rejikumar, Raja \& Saha (2019) have suggested that consumers expectations in the insurance industry are constantly changing and increasing. Thus, sustainability in the industry will only be in the service quality and initiatives taken by insurance companies to align its service quality towards customer expectation. However, these findings also suggest that for a short-term insurance contract, trust/loyalty and price are not important factors on switching intention as the coverage as well as price are perceived to be equivalent between one insurance company to another.

\section{References}

Ajzen, I. (1991), 'The Theory of Planned Behavior, Organizational Behavior and Human Decision Processes', 50, 179-211.

Anto'n, C., Camarero, C., \&Carrero, M. ( 2007), 'Analyzing firms' failures as determinants of consumer switching intentions: The effect of moderating factors', European Journal of Marketing, 41, 1/2, 135-158.

Asunción, B., Martin, J. D., \& Quintana, A. (2004), 'A Model of Customer Loyalty In The Retail Banking Market', European Journal of Marketing, Vol. 38, Iss 1/2, pp. 253 - 275.

Clemes, M. D., Gan, C., \& Zheng, L. Y. (2007), 'Customer Switching Behavior In The New Zealand Banking Industry', Banks and Banks System, Vol. 2 No. 4, pp. 50-66.

Consumer Insurance Sentiments. (2014). Retreived from http://www.nielsen.com/us/en/insights/reports/2014/2014-consumer-insurancesentiments.html

Fogli, L. (2006), 'Customer Service Delivery', Jossey-Bass, San Francisco.

Harrison, M. P., Beatty, S. E., Reynolds, K. E., Noble, S. M. (2012), 'Why Customers Feel Locked into Relationships: Using Qualitative Research to Uncover Lock-in Factors', Journal of Marketing Theory and Practice, Vol. 20, No.4, pp. 391-406.

Lin, W-B. (2010), 'Service Failure And Consumer Switching Behaviors: Evidence From The Insurance Industry', Expert Systems with Applications, Vol. 20, No. 3, pp. 709-734.

Lyman, M. (2014). The 'Switching' Economy: Consumers Open to Buying Insurance from Google, Amazon, Verizon. Retrieved from http://www.insurancejournal.com/news/national/2014/02/07/319835.htm

Mayer, R. C., Davis, J. H., \& Schoorman, F. D. (1995), 'An Integrative Model of Organizational Trust', Vol. 20, No. 3, pp. 709-734. Narayandas, D. (1998), 'Measuring and Managing the Benefits of Customer Retention: An Empirical Investigation', Journal of Service Research 1 (November): 108-128. 
INTERNATIONAL JOURNAL OF ACADEMIC RESEARCH IN BUSINESS AND SOCIAL SCIENCES

Vol. 10, No. 3, March, 2020, E-ISSN: 2222-6990 @ 2020 HRMARS

Perera, S., \& Gamage, S. (2019). 'Determinants of the Customer Satisfaction in Motor Insurance'. Saudi Journal of Business and Management Studies, 4(9), pp 754-764

Rejikumar, G., Raja S. V., \& Raiswa, S. (2019). 'An integrated framework for service quality, choice overload, customer involvement and satisfaction Evidence from India's non-life insurance sector'. Management Decision, pp 1-28

Saeed, A., Hussain, N., \&Riaz, A. (2011), 'Factors Affecting Consumers' Switching Intention', European Journal of Social Sciences, Vol. 19, No. 1.

Sambandam, R., \& Lord, K. R. (1995), 'Switching Behavior in Automobile Market: A ConsiderationSets Model', Journal of the Academy of Marketing Science, 23 (1), 57-65.

Srivastava, M., \& Rai, A. K. (2014), 'An Investigation into Service Quality-Customer Loyalty Relationship: The Moderating Influences', 41(1):11-31.

Zeithaml, V. A. (1988), 'Consumer Perceptions of Price, Quality and Value: A Means End Model and Synthesis of Evidence', Journal of Marketing, Vol. 60, pp. 31-46. 